\title{
Challenges Faced by SMEs in Oman
}

\section{OPEN ACCESS}

Volume: 7

Issue: 1

Month: July

Year: 2019

ISSN: 2321-788X

Received: 16.05.2019

Accepted: 28.05.2019

Published: 01.07.2019

Citation:

Ramachandran, Nithya, and Hanan Mohammed Ali AL Yahmadi. "Challenges Faced by SMEs in Oman." Shanlax International Journal of Arts, Science and Humanities, vol. 7, no. 1, 2019, pp. 15-25.

DOI:

https://doi.org/10.34293/ sijash.v7i1.496

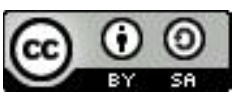

This work is licensed under a Creative Commons Attribution-ShareAlike 4.0 International License

\author{
Nithya Ramachandran \\ Faculty, Accounting and Finance Section \\ Department of Business Studies, IBRA College for Technology, Sultanate of Oman
}

\section{Hanan Mohammed Ali AL Yahmadi}

Accounting and Finance Section

Department of Business Studies, IBRA College or Technology, Sultanate of Oman

\begin{abstract}
SMEs play a significant role in income generation, labour absorption, poverty alleviation and contribution to gross domestic product. The significant challenges faced by them are Lack of basic business knowledge, Lack of market knowledge and information, Lack of adequate finance, complicated procedures and delay in loan disbursement, Limited network, experience and expertise, Reluctant in using modern technology. The study objectives are: to identify the obstacles faced by SMEs in Oman, to understand the difficulties encountered in accessing finance by SMEs in Oman and to study the relationship between the availability of funding and performance of SMEs. The required data were collected using structured Questionnaire from 102 respondents' selected using simple random sampling method. The results show that $47.1 \%$ and $37.2 \%$ of the respondents felt that gender and age are not an obstacle. Around 54 respondents have ranked that their funds were used for their business while loans from commercial banks were listed as number 2 for accessing finance by 35 respondents. Out 22 respondents who have applied for a bank loan, 13 respondents have faced difficulties in obtaining it. Poor business performance has been ranked number 1, followed by inadequate business planning as a reason for the failure of a bank loan. SMEs need adequate training, finance, and teaching entrepreneurial culture among students.
\end{abstract}

Keywords: SMEs, access to finance, challenges faced by SMEs, business performance, training, entrepreneurial culture.

\section{Introduction}

A country's economic development lies in better industrial growth and advancement in technology. The faster phase of globalisation has forced states to concentrate on entrepreneurial development also. Fresh graduates must be taught with an entrepreneurial culture, which will boost the young talents and will stimulate economic growth and development. Encouraging entrepreneurial activities will decrease the problem of unemployment faced by many countries. Adequate training and financial assistance provided to young entrepreneurs will get them on track towards the country's economic development.

Unemployment has become a significant concern for the policymakers in Oman. The unemployment rate increased to 16 per cent in 2017, from 15.80 per cent in 2016 (https://tradingeconomics.com, n.d.). The government takes the initiative to create employment opportunities and at the same time, encourages graduates to start their own business. The government of Oman introduced the concept of In-Country Value (ICV) for the oil and gas sector in the year 2013 , which was aimed to create 50,000 jobs by 2020 . ICV is the total amount spent, which is retained in the country that can benefit business development, contribute to human capability and also stimulate productivity in the economy. In short, the products are made and services that are provided by skilled Omanis. (Ms. Halima Ali Al Shezawi, 2018). 
Sultanate of Oman is intensively working to reduce its dependency on hydrocarbons and looking for adequate economic diversification. The economic diversification is aimed to create rapid growth in the economy. The government plans and moves forward to attract more foreign direct investment, creating more job opportunities to tackle the problem of unemployment created by more entrants in the job market. The government also takes practical steps to attract more private investments in the country, especially in Small and Medium Enterprises (SMEs). (Joharib, 2015).

SMEs play a significant role in Oman's economic development; they also tend to reduce unemployment problems and also dependency on hydrocarbon. Hence the government takes necessary steps in providing adequate training to upcoming entrepreneurs and even needed assistance in funding them through various financial institutions/schemes. (Badriya Hilal Said Al Bulushi, March 2017).

On the other hand, private sectors also play a significant role in improving SMEs by providing training and financial assistance, charging modest interest for those people who want to start their own business. SMEs plays a vital role in income generation, labour absorption, poverty alleviation and contribution to gross domestic product (GDP).

There are many challenges faced by them. The major problems are:

- Lack of basic business knowledge

- Lack of market knowledge and information

- Lack of adequate finance, complicated procedures and delay in loan disbursement

- Limited network, experience and expertise

- Reluctant in using modern technology

\section{Review of Literature}

Many researchers have studied about SMEs in different views. The general area of the study is on the financial aspects of SMEs. The studies outline the source of capital, difficulties encountered and fear of failure of SMEs.

Jamal AlMaimani, Fuadah Binti Johari, (2015), Enhancing Active Participation of SMEs and Islamic Banks towards economic diversification in Oman, Procedia Economics and Finance, 31 (2015) pp. 677 - 688. This study noted, Oman trying to reduce hydrocarbons to achieve economic diversification by developing plans and strategy to achieve this goal. Also, this plan and strategy help to support trade and repaid growth of the economy. Therefore, the government is working hard to achieve its objective by providing financial assistance to the owner of the idea and providing funding for them to open their own business. However, these people face challenges to open (SMEs) such as Lack of business basic knowledge, Difficulty to access finance and the limited use of modern technology due to its limited resources and expert knowledge. Finding the result of this study is how the government can help people to start their own business (Jamal AlMaimania, 2015)

Jesús Salvador Vivanco Florido, Martha Gonzalez Adame, Miguel Angel Oropeza, (2015), Financial strategies, the professional development of employers and performance of SME's, Procedia Social and Behavioral Sciences, 174 (2015) pp. 768 775. The study is done to understand the importance of small enterprises in a country. The research is done on how SMEs help in the development of an individual in the way of enhancing their experience and knowledge, which will be a source of income for the SMEs. It is shown in the study that the government of Oman has realised the importance of having more SMEs in the country under the Ministry of Commerce and Industry. The significant challenges faced are grouped into three categories, which are Community-related challenges, investment challenge and finally readiness of the entrepreneurs as a challenge. The study result was found that large enterprises are planning to start with SME support services through support programs. (Florido, 2015)

Dr Allen Baby, CA. Ciby Joseph, (2016), Bank Finance Challenges Faced by UAE SME Sector, Arabian Journal of Business and Management Review, 4172/2223-5833. The study tends to study the challenges faced by SMEs in accessing to finance from banks. SMEs face more challenges when it comes to its financial requirements. Even though SMEs have obtained funds with great difficulty from banks, maintaining the business and proper monitoring of the market will be a big challenge to the business owners. The results of the study showed that SME financing faces drawbacks like poor 
financial discipline, dishonesty character of business executive and using the access of short term bank funds. (Allen Baby, 2016)

Growth Strategies of SMEs in Oman- Issues and Challenges, International Journal of Small Business and Entrepreneurship Research, Vol.5, No.2, pp.2161, March 2017, Badriya Hilal Said Al Blush. The author has conducted a study to determine the Growth Strategies of SMEs in Oman and the challenges faced by SMEs to improve their performance. SMEs face a lot number of problems during their implementation stage and in the growth stage. To promote SMEs, the government also provides training, financial facilities, a guideline to run their business. The main challenge the SMEs face do not know the success strategy, which can be had only by experience, not by training. (Badriya Hilal Said Al Bulushi, March 2017).

Identification of Financial Strategy in Small and Medium-Sized Entrepreneurship Acta Universities Agriculture Et Silviculturae Mendelianae Brunensis. This study shows that financial performance is one of the fundamental problems of business management, which is to set the total optimal amount of capital. Also, this study discussed issues that may face by the manager when risking significant money to start their own business. In addition, reason of failure SME which are: Insufficient cash flow One of the most common shortcomings of SME is bad debts of customers, Uncontrolled expansion, lack of cash flow, the absence of production and business strategy, lack of contacts and orientation in industry and Insufficient experience and knowledge on the side of managers and entrepreneurs. So this study provides solutions to reduce these problems faced by SMEs. (Svatošová, 2017)

Challenges and Barriers Encountered by the SME Owners in Muscat. International Journal of Small Business and Entrepreneurship Research Vol.2, No.3. Pp.1-13 September 2014. The study has pointed out that both developed countries and also developing countries and their governments have accepted the reality that SMEs play an essential role in their economic development. It is stated that SMEs contributions to the socio-economic development of a country are always remarkable. The projects which have less amount of investment earn more profit and are stable when compared to significant investment concerns. The SMEs has also encouraged women empowerment. (Blossom Christina, 2014)

Impact and Role of SME Bank Loans in Oman, International Journal of Humanities and Social Sciences (IJHSS). The study aims to show how SMEs are essential in creating adequate employment opportunities. How SMEs help in improving the Gross Domestic Product of a country. The major challenge of SMEs is not having sufficient knowledge of marketing the goods produced by them, lack of adequate training for running a business, lack of adequate contacts which can help the business development. The information exchanged by the SMEs is comparatively less. There is no growth trend that shows an only top pattern, which is continuous growth. This study noted when start (SMEs) we should respect Legal Environment, Economic environment, Competitive environment, Demographic environment, Physical environment, Technological environment, Demographic environment, Social, cultural environment and Political environment. (A.O.Akinila, 2014)

\section{SMEs in Oman}

The Public Authority for Small and Medium Enterprises Development (Riyadh) is an arm for the development of SMEs in Oman. The authority tends to strengthen their contribution by providing training and instructional programs to the local economy. The agency called Riyadh was established as the Public Authority for Small and Medium Enterprises Development as per Royal Decree No, 36/2013, it has both financial and administrative autonomy and its headquarters is in Muscat. It has adequate rights to establish branches in the other governates based on the necessity which is allowed as per resolution from its board of directors. In under the decision issued by the Ministry of Commerce and Industry in January 2016, the classification of SMEs based on several workforces and annual sales are as below: 
International Journal of Arts, Science and Humanities

\section{Table 1 New SME classification}

\begin{tabular}{|l|c|l|}
\hline Classification & $\begin{array}{c}\text { Number of } \\
\text { workforces }\end{array}$ & \multicolumn{1}{c|}{$\begin{array}{c}\text { Annual sales } \\
\text { (OMR) }\end{array}$} \\
\hline Micro & $1-5$ & Less than 100,000 \\
\hline Small & $6-25$ & $100,000-500,000$ \\
\hline Medium & $26-99$ & $\begin{array}{l}500,000-\text { less than } \\
3,000,000\end{array}$ \\
\hline Large & More than 99 & $3,000,000$ and above \\
\hline
\end{tabular}

Source:http://www.incountryvalueoman.net/ getattachment/d7f2d623-6be0-467c-8a78e4f170233acd/New-SME-Classification

The total number of SMEs registered with Riyadh at the end of August 2018 was 35,596 recording a rise compared to the end of July 2018, which was 35,381. The percentage of SMEs registered governate wise at the end of August 2018 is as below:

Table 2 Governate wise percentage of SMEs expressed

\begin{tabular}{|l|c|}
\hline \multicolumn{1}{|c|}{ Governates } & $\begin{array}{c}\text { Number of SMEs } \\
\text { registered }\end{array}$ \\
\hline Muscat & 10,490 \\
\hline AL Batinah North & 4,988 \\
\hline AL Batinah South & 2,403 \\
\hline Ad Dakhliyah & 4,402 \\
\hline A'Dhahirah & 2,086 \\
\hline Dhofar & 2,850 \\
\hline A'Sharqiyah North & 2,278 \\
\hline A'Sharqiyah South & 1,877 \\
\hline AL Buraymi & 590 \\
\hline AL Wasta & 359 \\
\hline Musandam & 118 \\
\hline \multicolumn{1}{|c|}{ Total } & $\mathbf{3 2 , 4 4 1}$ \\
\hline
\end{tabular}

Source: https://www.ncsi.gov.om/News/Pages/ NewsCT_20181008080531695.aspx

\section{SMEs Service Providers in Oman}

SMEs in Oman are supported by many service providers; few notable service providers are listed below:

\section{SMEF}

The SME Development Fund, an Omani Fund incorporated in the year March 2014 which is aimed to provide finance to the SMEs in Oman. The Fund is licensed by the Capital Market Authority
(CMA) and managed by National Company for Projects and Management LLC (NCPM). The fund is an initiative created and established by the Omani Authority for Partnership for Development. The primary objective for the establishment of the SMEF is to provide adequate financing facilities to SMEs. The SMEF has incubators in college campuses, which encourages students and graduates to move from job search to job creation segment. (https://www.smefoman.com/, n.d.)

\section{Al Rafd}

On January 1, 2012, the actual activity of the AlRafd Fund was launched through the first package of funding programs. The fund was established with four financing programs, which includes resource requirements, establishment requirements, entrepreneurship requirements and promotional assistance, which were the needs of the target groups. The majority of job seekers were graduates. So this fund aimed to provide facilities to graduates, women in rural areas and other professionals. (https://www. alraffd.gov.om/ar/Default.aspx, n.d.)

\section{Bank Sohar}

Bank Sohar is a leading private sector bank aimed to provide financial assistance to SMEs and aimed to promote an entrepreneurial culture and aimed to promote sustainable development in Oman. The bank to achieve the aim offers commercial facilities to the required and adequately proposed business having a turnover up to OMR 3.0 million and maximum exposure of OMR 2.5 Million to provide the SME entrepreneurs with superior \& faster services. (http:// www.banksohar.net/Corporate-Banking/Aafaaq-AlNajah-SME/Overview, n.d.)

\section{Oman Arab Bank}

Oman Arab Bank provides financial assistance for SMEs in Oman. The bank has many new ideas under the scheme of TIMOTHY scheme, which covers working capital finance, capital expenditure loans, contracts and equipment finance, import and export finance and other types of finance suitable for a business. (http://www.oman-arabbank.com/home/ corporate-banking/small-and-medium-enterprises/, n.d.) 


\section{National Bank of Oman}

The National Bank of Oman has been in the scheme of providing financial assistance to SMEs in Oman for quite a long time. They provide quick and easy financial products processing through their simple documentation process, flexibility in repayment, corporate internet banking, etc. (www. nbo.om/en/Pages/SME-Banking/Products-andServices/SME-Services.aspx, n.d.)

\section{Bank Nizwa}

Bank Nizwa, a leading private commercial bank which has to its credit as the first Islamic banking sector started in Oman. Bank Nizwa also assists SMEs by providing loan to the business units through a product called as Sharia-compliant products. The scheme is dedicated SME Banking team with indepth knowledge of Islamic Banking principles. The bank helps to the financial needs of SME clients operating in various sectors of the economy through public Sharia contracts, such as Murabaha, Ijarah, Mudarabah,etc.(www.banknizwa.om/services/ some-banking, n.d.)

\section{Ahli Bank}

Ahli Bank provides various products to the SMEs in Oman through various schemes to develop the diversified SMEs sector in the region. The bank works with a separate SMEs banking division with a team of customer-relationship management executives. The bank provides help to SMEs to express their full potential with more response and various product packages. (www.alhilal.om/sme/, n.d.)

\section{Research Methodology \\ Statement of the Problem}

SMEs are gaining importance and play a significant role in increasing domestic production and providing employment opportunities. The government is taking necessary actions to bring out a businessman attitude in all graduates. The changes in the curriculum to teach entrepreneurial skills in graduates is the best example of it. The government has also taken steps for providing adequate finance to the SMEs but are these facilities reaching the required beneficiaries and are the funds used productively. As a result, the primary reason for choosing this study title was:

- Banks have special schemes for providing loans for SMEs, but such projects are not fully used productively by SMEs.

- Lack of employment opportunities tends to start a new business. Thus such business entrepreneurs do not have adequate knowledge and expertise to overcome the challenges and run the market for an extended period.

Even though there are many challenges faced by SMEs, finance plays a vital role in any business, so a comprehensive study on SMEs are financing is the need of the hour.

\section{Research Questions}

The research has aimed to find a solution for the following research questions:

1. Are SMEs facing difficulty in meeting their financial obligations? (objective 2)

2. What are the obstacles faced by SMEs when obtaining finance through banks and other financial schemes? (goal 2)

3. What is the effect of financing an inability on the performance of SMEs? (objective 3)

4. What factors have a significant impact on SMEs accessing finance? (goal 2)

5. What are the various sources of funding available for SMEs in Oman?

6. Do the available financing products and services meet the requirements of SMEs?

\section{Research Objectives}

The following study objectives were framed to find clarification for the above-stated research questions.

1. To identify the difficulties encountered by SMEs in Oman.

2. To identify and understand the difficulties faced in accessing finance by SMEs in Oman.

3. To study the relationship between the availability of finance and performance of SMEs.

\section{Research Environment}

The primary aim of the study is about the SME sector of Sultanate of Oman. In the current economic development scenario, SMEs has a significant role to 
play as they pave the way for long-term sustainable growth and reduce the dependence on oil and gas alone. The Sultanate of Oman located in the Arabian Peninsula is geographically segmented into nine regions. They are Muscat, Dhofar, Musandam, A'Sharqiyah, AL Batinah, A'Dakhiliyah, A'Dhahirah, AL Buraymi, and AL Wasta. This study is intended to collect data from around 102 SMEs covering all the regions of Oman.

\section{Research Design}

The samples are selected using a simple random sampling method.A simple random sample is one which is an unbiased surveying technique. According to the principle of simple random sampling, every study object has an equal probability of being chosen for the study purpose. This sampling method is used to reduce a large population to a smaller size and use the sample for the research purpose, which can later be generalised for the astronomical community. This sampling method is easy to use and accurately represents a large population.

The sampling method selected for the study purpose can be applied in a step-by-step manner.

- Step 1: Defining the population of the study

- Step 2: Choosing the sample size

- Step 3: Assign numbers to the sample units

- Step 4: Find random numbers

- Step 5: Select the sample for further data collection and analysis.

\section{Research Procedure and Research Instrument}

The research aimed to collect questionnaires from 120 respondents but was able to distribute 110 surveys only. Out of which 105 was received back and by further scrutiny found that only 102 questionnaires were found useful and used for further analysis. The study used primary data collected from the respondents using a structured questionnaire. The quiz consists of three sections.

- Section 1 covers the background information of the business

- Part 2 includes questions related to business obstacles faced by SMEs

- Chapter 3 covers issues related to accessing finance by SMEs

\section{Study Period}

The research work was undertaken for a period of 3 months, which was from January - March 2019.

\section{Limitations of the Study}

The research design that influences the findings of the research is a characteristic of research limitation. Restrictions can be general, applications to practice, methods used for internal or external validity, etc. the following are the limitations of the current study.

\section{Study Design Limitation}

- The probability of receiving an exact outcome from the respondents.

- Undertaken as a single approach from SMEs only.

\section{General Limitation}

The time limit for the study has restricted data collection from banks and financial institutions.

\section{Data Analysis}

\section{Section 1: Background Information Type of Business}

Finding out the kind of business run by the SMEs will be useful for the study purpose, and the questionnaire included the question on type of business. The percentage analysis of the problem is given in the table below.

Table 3: Type of Business

\begin{tabular}{|c|c|c|}
\hline $\begin{array}{c}\text { Type of } \\
\text { Business }\end{array}$ & $\begin{array}{c}\text { No. of } \\
\text { respondents }\end{array}$ & \% \\
\hline Service & 75 & $73.5 \%$ \\
\hline Manufacturing & 27 & $26.5 \%$ \\
\hline Total & $\mathbf{1 0 2}$ & $\mathbf{1 0 0 \%}$ \\
\hline
\end{tabular}

Source: primary data

Table 3 shows that around $73.5 \%$ of the businesses that have participated in this study were from the service sector; about $26.5 \%$ of the total sample are from the manufacturing industry.

\section{Annual Sale Turnover of the Business}

Based on the SME classification system, firms with an annual sales turnover not more than 300,000 OMR are micro, small and medium enterprises, and firms with above 300,000 OMR annual sales turnover are medium enterprises. 
International Journal of Arts, Science and Humanities

Table 4 Annual Sales Turnover

\begin{tabular}{|c|c|c|}
\hline \multicolumn{1}{|c|}{ Annual sales } & $\begin{array}{c}\text { No. of } \\
\text { respondents }\end{array}$ & \% \\
\hline Less than 100000 & 48 & $47.5 \%$ \\
\hline $100000-300000$ & 38 & $37.6 \%$ \\
\hline $300000-500000$ & 12 & $10.9 \%$ \\
\hline $5000000-1000000$ & 4 & $4 \%$ \\
\hline$>1000000$ & 0 & $0 \%$ \\
\hline Total & $\mathbf{1 0 2}$ & $\mathbf{1 0 0} \%$ \\
\hline
\end{tabular}

Source: primary data

Table 4 illustrates that the majority $(n=48,47.5 \%$ per cent) of the respondents have their annual turnover of less than 100000 OMR. The other notable cohort ( $n=38,37.6 \%$ per cent) was businesses which have an estimated annual turnover of between 100000 and 300000 OMR (Table1). Thus, there were more small- sized enterprises $(85.1(47.5+37.6)$ per cent $)$ than medium-sized ones $(14.9(10.9+4)$ per cent $)$ in the sample.The response to the estimated annual sales turnover from 500000 OMR and more than 1000000 OMR was inadequate. The reason for reducing the number of response was difficulty in obtaining loan from bank and lack of advertising and marketing.

\section{Section 2: Obstacles Faced by Smes in Oman Objective 1: To Identify the Obstacles Faced by SMEs}

To study the obstacles faced by the respondents in their business, questions were framed on six different factors consisting of gender, age, education, work experience, availability of capital and lack of training.

Table 5 Obstacles faced by SMEs

\begin{tabular}{|c|l|c|c|c|c|c|}
\hline S. No & \multicolumn{1}{|c|}{ Study Factor } & $\begin{array}{c}\text { Major } \\
\text { Obstacle }\end{array}$ & $\begin{array}{c}\text { Moderate } \\
\text { obstacle }\end{array}$ & $\begin{array}{c}\text { Not an } \\
\text { obstacle }\end{array}$ & $\begin{array}{c}\text { Less } \\
\text { obstacle }\end{array}$ & $\begin{array}{c}\text { Very less } \\
\text { obstacle }\end{array}$ \\
\hline 1 & Gender & $18(17.6)$ & $13(12.7)$ & $48(47.1)$ & $12(11.8)$ & $11(10.8)$ \\
\hline 2 & Age & $38(37.2)$ & $24(23.5)$ & $18(17.6)$ & $14(13.7)$ & $8(7.8)$ \\
\hline 3 & Education & $17(16.7)$ & $27(26.5)$ & $33(32.4)$ & $16(15.7)$ & $9(8.8)$ \\
\hline 4 & Experience & $39(38.2)$ & $25(34.5)$ & $20(19.6)$ & $15(14.7)$ & $3(3)$ \\
\hline 5 & Availability of Capital & $47(46.1)$ & $37(36.3)$ & $8(7.8)$ & $6(5.9)$ & $4(3.9)$ \\
\hline 6 & Lack of Training & $42(41.2)$ & $23(22.5)$ & $13(12.7)$ & $8(7.8)$ & $16(15.7)$ \\
\hline
\end{tabular}

Source: primary data. Figures in brackets indicate percentages.

To study the obstacles faced by the respondents, six factors were selected. The first study factor was the gender of the respondents. Out of the total respondents, $47.1 \%$ of them felt that gender is not an obstacle for their business. The second study factor was age, which stated that $37.2 \%$ of the respondents thought it as a significant obstacle, and $23.3 \%$ of the respondents felt that age is a moderate obstacle. The third study factor was the education of the respondents for which $32.4 \%$ of them thought that it is not an obstacle, and $26.5 \%$ of them felt that it is a moderate obstacle. The fourth study factor was an experience for which $38.2 \%$ of them answered as a significant obstacle and $34.5 \%$ of them felt that it is a moderate obstacle. The fifth study factor being the availability of capital for their business, which was started by $46.1 \%$ of the respondents as a significant obstacle and $36.3 \%$ of the respondents as a moderate obstacle. The last study factor was lack of adequate training for which $41.2 \%$ of the respondents felt it as a significant obstacle, and $22.5 \%$ of the respondents felt that as a moderate obstacle for running their business.

\section{Section 3: Accessing Finance by SMES in Oman Objective 2: To Identify and Understand the Difficulties Faced in Accessing Finance by SMES Sources of finance}

To know the various sources of funding accessed by the respondents, the following question was designed, and the results are as below: Questions were classified into six broad categories; personal resources, relatives and friends, commercial bank, Islamic bank, and government-supported funds. 


\begin{tabular}{|l|c|c|}
\hline \multicolumn{1}{|c|}{ Table 6 Sources of Finance } \\
\hline Sources of finance & $\begin{array}{c}\text { Number of } \\
\text { respondents }\end{array}$ & Rank \\
\hline Personal resources & 54 & 1 \\
\hline Commercial Bank & 35 & 2 \\
\hline Islamic Bank & 31 & 3 \\
\hline Relatives/Friends & 20 & 4 \\
\hline Government Sector Funds & 27 & 5 \\
\hline Private Sector Funds & 19 & 6 \\
\hline
\end{tabular}

Source: primary data.

Table 6 clearly shows that for a maximum number of respondents (54), personal resources is being the primary source of finance. A commercial bank loan is the second source of funding for 35 respondents while the loan from an Islamic bank has been the third source of finance for 31 respondents. The respondents have sourced their funds from their friends and relatives, which has been ranked as the fourth source whereas government sector funds and private sector funds have been listed in the fifth and sixth places, respectively.

\section{Reasons for Seeking Finance}

The study aimed to find out the purpose for which SMEs were accessing finance. The various reasons identified and the respondents' opinion results are showed as below:

Table 7 Reasons for Seeking Finance

\begin{tabular}{|l|c|c|}
\hline \multicolumn{1}{|c|}{$\begin{array}{c}\text { Reasons for } \\
\text { Seeking Finance }\end{array}$} & $\begin{array}{c}\text { No. of } \\
\text { respondents }\end{array}$ & Rank \\
\hline Purchase of Raw Material & 47 & 1 \\
\hline Working Capital & 60 & 2 \\
\hline Acquisition of Fixed Assets & 29 & 3 \\
\hline Expand Business & 18 & 4 \\
\hline
\end{tabular}

Source: primary data

Table 7 was created to study the reasons for which the respondents were opting finance. It would be better understood the purpose or usage of investment obtained from different sources. The goal identified was the purchase of material which was ranked at number 1st position by 47 respondents, followed by working capital usage at number 2nd position by 60 respondents. Acquisition of fixed assets and expanding the business being in the 3rd and 4th rank with 29 and 18 respondents, respectively.

\section{Applying for Bank Finance}

It was found to be essential to know whether SMEs approach a bank or a financial institution for their funds and the results of the question are as below:

Table 8 Applying for Bank Finance

\begin{tabular}{|c|c|c|}
\hline Category & No. of respondents & $\%$ \\
\hline Yes & 22 & $21.6 \%$ \\
\hline No & 80 & $78.4 \%$ \\
\hline
\end{tabular}

Source: primary data.

The above table gives a clear picture that $78.4 \%$ of the respondents have not approached a bank or a financial institution for obtaining funds for their business. But $21.6 \%$ of the respondents have approached a bank or a financial institution for seeking funds for their business.

\section{Difficulties in Obtaining Funds from Omani Banks}

The respondents who have approached a bank or a financial institution (22) were asked to answer whether they faced any challenge in obtaining finance, and the results of the question are as below:

Table 9 Difficulties in obtaining funds

\begin{tabular}{|c|c|c|}
\hline Category & No. of respondents & \% \\
\hline Yes & 13 & $59 \%$ \\
\hline No & 09 & $41 \%$ \\
\hline
\end{tabular}

Source: primary data.

The above table gives a clear picture that $59 \%$ of the respondents have approached a bank or financial institution for accessing a loan and faced difficulties in obtaining it whereas $41 \%$ of the respondents have approached a bank or a financial institution for a loan but not encountered any problems in getting it.

\section{Reasons for Failure in Accessing Bank Finance}

To study in detail, the reason for the difficulties faced by the respondents. The 13 respondents who declared that they had faced problem were asked to rank the reason for such a problem, and the results are given below. 
Table 10 Reasons for Failure in accessing bank finance

\begin{tabular}{|l|c|c|}
\hline \multicolumn{1}{|c|}{$\begin{array}{c}\text { Reasons for Failure in } \\
\text { obtaining bank finance }\end{array}$} & Number & Rank \\
\hline Poor business performance & 5 & 1 \\
\hline Inadequate business planning & 3 & 2 \\
\hline Don't meet requirements & 3 & 3 \\
\hline Lack of credit record & 2 & 4 \\
\hline
\end{tabular}

Source: primary data.

The above table clearly shows that poor business performance was the reason ranked at number 1 for the failure of access to bank finance, followed by inadequate business planning as the second reason. Did not meet the requirements and lack of credit record is in the 3rd and 4th ranked reason for the failure of bank finance.

Objective 3: To Study the Relationship between Availability of Finance and Performance of SME
Effect of Difficulties in Accessing Finance on Business Performance

To study whether the non-availability of finance has affected the performance of the business, the respondents who have faced difficulties (13) were asked whether the problems faced by them has impacted their business performance.

Table 11 Effect of Accessing Finance on Business Performance

\begin{tabular}{|l|c|c|}
\hline Category & No. of respondents & \% \\
\hline Yes & 09 & $69 \%$ \\
\hline No & 04 & $31 \%$ \\
\hline
\end{tabular}

\section{Source: primary data.}

The above table provides information that out 13 respondents who faced difficulties in accessing finance, $69 \%$ (9) respondents hurt their business performance and $31 \%$ (4) respondents did not have an impact on their business performance.

\section{Relevance of Past Studies}

\begin{tabular}{|c|c|c|c|c|}
\hline S.No & iterature review & Feature & Past literature & Current study \\
\hline \multirow{3}{*}{1} & \multirow{3}{*}{$\begin{array}{l}\text { Enhancing Active } \\
\text { Participation of } \\
\text { SMEs and Islamic } \\
\text { Banks Towards } \\
\text { Economic } \\
\text { Diversification } \\
\text { in Oman (Jamal } \\
\text { AlMaimania, } \\
\text { 2015) }\end{array}$} & Study objective & $\begin{array}{l}\text { To explore and analyse SME } \\
\text { situation in Oman and the support } \\
\text { it is getting from the Government } \\
\text { and the private sector }\end{array}$ & $\begin{array}{l}\text { To identify and understand } \\
\text { the difficulties faced in } \\
\text { accessing finance by SMEs. }\end{array}$ \\
\hline & & Study Results & $\begin{array}{l}\text { Although there are many } \\
\text { initiatives, which have been } \\
\text { designed to promote and } \\
\text { support Small and Medium } \\
\text { Enterprises (SMEs), there are } \\
\text { still many efforts needed to } \\
\text { apply such plans practically on } \\
\text { the ground. In some cases, due } \\
\text { to multiple programs introduced, } \\
\text { the entrepreneurs might face } \\
\text { confusion and difficulty to } \\
\text { select the appropriate type of the } \\
\text { application or institution which } \\
\text { he/she finds suitable to start-up } \\
\text { his/her business as a first step. }\end{array}$ & $\begin{array}{l}\text { Fifty-four respondents } \\
\text { have stated that they } \\
\text { have used personal } \\
\text { resources. } \\
\text { Eighty of the } \\
\text { respondents have opted } \\
\text { a bank loan as their } \\
\text { source of finance. } \\
\text { Sixty of them have faced } \\
\text { difficulties in getting } \\
\text { their bank loan. } \\
\text { The reason for rejection } \\
\text { of loan for around } 24 \\
\text { respondents was poor } \\
\text { business performance. }\end{array}$ \\
\hline & & $\begin{array}{l}\text { Recommendations } \\
\text { based on the } \\
\text { current study }\end{array}$ & \multicolumn{2}{|c|}{$\begin{array}{l}\text { It is obvious from the survey that the SMEs are aware of the } \\
\text { financial support provided by the government and the banks. } \\
\text { However, they need adequate training to improve their business } \\
\text { performance. }\end{array}$} \\
\hline
\end{tabular}




\section{Findings}

The following are the findings of the study:

- Among the respondents, $40 \%$ of the businesses were from the Retail sector.

- The type of business was highest having trade (import/export) of $43 \%$.

- The majority of the business was earning an annual turnover of less than 100000 which was $85.1 \%$

- Bulk (48) respondents have stated that their company belongs to sole proprietorship business

- Majority of the company, $83.3 \%$ has its owner as manager

- Around 49 respondents have 1-5 years of experience, and 49 respondents have 6-10 years' experience.

- Most of the respondents are having bachelor level of education $(25.5 \%)$

- Majority of the respondents (53) had undergone training before they started their business.

- Gender is not an obstacle for the business. Answered by $47.1 \%$

- Age of the respondents is not an obstacle (39.2\%)

- Education level is not an obstacle (32.4\%)

- Work experience is a significant obstacle (38.2\%)

- Availability of capital is a considerable obstacle $(46.1 \%)$

- Lack of training is a substantial obstacle (43.1\%)

- Sources of finance - personal resources ranks number one with 54 respondents

- Reasons for seeking investment: working capital ranked second, and purchase of raw material ranked as first.

- Majority of the respondents $78.4 \%$ have applied for a bank loan

- Majority of the respondents $70.6 \%$ have faced difficulties in obtaining a bank loan

- For $58.8 \%$ of the respondents' difficulty in getting a loan has affected their business performance.

- The primary reason for rejection of loan application is poor performance.

\section{Research Implications}

The following are the research implications based on the study results:

\section{Adequate Finance}

From the study, it is clear that SMEs opt either bank loan or government funds to source their funds for the business. However, the SMEs are not instructed/taught about the finance facility available and the procedures to be followed. The banks and other financial institutions, which are providing finance to SMEs, must give them a complete picture of policies and procedures related to finance.

\section{Adequate Training}

The SMEs must be provided with sufficient training in developing a business idea, taking the approach to the next level for successful withstanding the business. Training provided during the period of education for the graduates will make them understand the requirements and continue their business successfully.

\section{Entrepreneurial Culture}

Fresh graduates must be taught with an entrepreneurial culture, which will boost the young talents and will stimulate economic growth and development. Encouraging entrepreneurial activities will decrease the problem of unemployment faced by many countries. Adequate training and financial assistance provided to young entrepreneurs will get them on track towards the country's economic development.

\section{Future Research}

The current study has been conducted with selected factors that are obstacles for the SMEs. Further study with additional elements and a comparative survey of GCC countries can be performed.

\section{Conclusion}

The study has provided the problems faced by the Oman SME sector in obtaining finance from Omani banks and government and private sector funds. The study has worked on studying and understanding the challenges and obstacle that the SMEs have faced. The study has summarised those obstacles in accessing finance and its significance to the financial performance of SMEs in Oman. In conclusion, the findings of this study should enable Omani banks, 
government and private funds, which should special attention and enhance their serving of the needs of SMEs. It also government provides contributions to provide finance and programs encourage people to start SMEs to diversify the economy by reducing the dependency of hydrocarbon. Both developing and developed countries in the world have shifted their focus on SMEs and Oman also has started its role, but the government should take practical steps to reduce the percentage of failure and closure of business due to lack of finance.

\section{References}

Akinila, AO. "Entrepreneurship: Funding and Financing Strategies in Nigeria." European Journal of Accounting Auditing and Finance Research, vol. 2, no. 4, 2014, pp. 39-51.

AlMaimani, Jamal, and Fuadah Binti Johari. "Enhancing Active Participation of SMEs and Islamic Banks." International Accounting And Business Conference, Science Direct, vol. 31, 2015, pp. 677-688.

Baby, Allen, and CA Ciby Joseph. "Bank Finance Challenges Faced by UAE SMEs." Arabian Journal of Business Management Review, 2016.

Bulushi, Badriya Hilal Said Al, and Sammena Bagum. "Growth Strategies of SME in OmanIssues and Challenges." International Journal of Small Business and Entrepreneurship Research, vol. 5, no. 2, 2017.

Christina, Blossom, et al. "Challenges and Barriers Encountered by the Smes Owners In." International Journal of Small Business and Entrepreneurship Research, vol. 2, no. 3,
2014, pp. 1-13.

Dodeen, Hamzeh M. "Undergraduate Students Are Cheating in Exams." Damascus University Journal, vol. 28, no. 1, 2012, pp. 37-55.

Florido, Jesús Salvador Vivanco, et al. "Financial Strategies, the Professional Development of Employers and Performance of SMEs." Social and Behavioral Sciences, vol. 174, 2015, pp. 768-75.

Shezawi, Halima Ali Al, and Firdouse Rahman Khan. "In-Country Value (ICV) - Entrepreneurial Opportunities In." International Journal of Management, Innovation \& Entrepreneurial Research, vol. 4, no. 1, 2018, pp. 25-41.

Svatošová, Veronika. "Identification of Financial Strategy in Small and Medium Sized Entrepreneurship." Acta Universitatis Agriculturae et Silviculturae Mendelianae Brunensis, vol. 65, no. 4, 2017, pp. 1435-53.

\section{Websites}

www.tradingeconomics.com

www.banksohar.net/Corporate-Banking/Aafaaq-Al-

Najah-SME/Overview

www.alraffd.gov.om/ar/Default.aspx

www.smefoman.com

www.ncsi.gov.om/News/Pages/

NewsCT_20180226072141034.aspx

www.oman-arabbank.com/home/corporate-banking/ small-and-medium-enterprises www.nbo.om/en/Pages/SME-Banking/Productsand-Services/SME-Services.aspx www.banknizwa.om/services/sme-banking www.alhilal.om/sme

\section{Author Details}

Dr.Nithya Ramachandran, Faculty, Accounting and Finance Section, Department of Business Studies, IBRA College for Technology, Sultanate of Oman. Email ID: nithya@ict.edu.om

Hanan Mohammed Ali AL Yahmadi, Accounting and Finance Section, Department of Business Studies, IBRA College or Technology, Sultanate of Oman. 